\title{
Factors Affecting Value Addition to Tea by Buyers within the Kenyan Tea Trade Value Chain
}

\author{
Tsalwa S. Grace \\ Jomo Kenyatta University \\ skalachu@yahoo.com
}

\author{
Theuri Fridah (PhD) \\ Jomo Kenyatta University \\ fridahtheuri@gmail.com
}

\begin{abstract}
Available data shows that though aware of the immense benefit of value addition, stakeholders in the Kenyan tea trade value chain, buyers included still to a great extent engage in the trade of the commodity most of which is not value added. This has made the country to continue to register massive loss in much needed revenue yearly apart from loss of other attendant benefits such as job opportunities. Though some research has been done on aspects of value addition to tea, a majority have tended to concentrate on educating stakeholders on the importance of value addition to tea. Thus, there is sparse empirical data on factors that could be inhibiting large scale operationalization of value addition to tea in Kenyan tea value chain. A descriptive survey study of buyers of Kenyan tea registered with the Mombasa tea auction market was designed to help seal this research gap by assessing the inhibiting factors with specific focus on buyers due to their strategic distributive role in the Kenyan tea trade value chain. The study attempted to determine how market destinations affect value addition of tea within the tea industry, to determine how Government policy effects value addition to tea by stakeholders in the tea industry, to determine how strategic decisions affect value addition of tea, to determine how personnel skill affects value addition. A total of 39 out of 55 active buyers at the Mombasa tea auction market participated in the study. Data was collected using self-administered questionnaires to managers of the tea buying companies. Results showed that a majority of the companies were involved in value addition to tea on small proportions.It was also showed that there is a significant relationship between buyers' strategic decisions, personnel skills and value addition to tea. Similarly, results showed that government policies, buyers' strategic decisions and personnel skills influence value addition to tea positively. However, market destination was found to influence it negatively. It is therefore recommended that that buyers diversify market destinations, the government put in place mechanisms aimed at addressing its policies inhibiting value addition to tea and management of the tea buying companies deliberately formulate policies aimed at encouraging value addition to tea including providing incentives to their employees involved in value addition.
\end{abstract}

Keywords: Value addition.

\section{INTRODUCTION}

Value addition in agriculture involves changes made to primary agricultural products such as tea that increases the product's value (TBK, 2014). This, among other things creates new economic activity in pre-production modifications that increase yields, quality and uses and diversify or modify the primary products. It also provides process activities that increases the net revenue generated by sale of the product and process activities that introduce the product to new markets. Simply speaking, value addition radically enhances the market value of a product. According to Ochanda (2012), lack of value addition on products usually results in stakeholders getting varying income depending on the market demand for their tea. However, with value addition they are certain to enjoy more stable prices and increased revenues emanating from the value added products. Table 1.1 provides information on tea export by Kenya and Sri Lanka between 2008 and 2013.

For instance, from Table 1, it is seen that in 2012 Kenya earned USD 1.33bn from export of $430 \mathrm{~m} \mathrm{kgs}$ of tea unlike Sri Lanka who in the same year earned USD $1.32 \mathrm{bn}$ from only $306 \mathrm{~m} \mathrm{kgs}$ owing to higher prices of its shipments due to more value addition (TBK, 2014). Thus, even though Kenya exported $41 \%$ more tea in quantity terms than Sri Lanka, the country earned a very similar quantity in value terms. Specifically, it is seen that there was a price difference of USD 1.24 for of every $\mathrm{kg}$ of tea between the two countries owing to value addition with price realization for Sri Lanka being USD $4.33 / \mathrm{kg}$ while for Kenya it was USD $3.09 \mathrm{~kg}$. The estimated difference of USD 1.24 per $\mathrm{kg}$ of tea between Sri Lanka and Kenya tea prices can also be referred to as the estimated loss per kg of tea sold in Kenya due to low value addition. In other words it can be concluded that Sri-Lanka earns higher 
return due to its value added tea which fetches a higher price than the Kenyan bulk tea in the world export market.

Table1.1. Tea Export

\begin{tabular}{|c|c|c|c|c|c|c|c|}
\hline & & 2008 & 2009 & 2010 & 2011 & 2012 & 2013 \\
\hline Kenya & $\begin{array}{c}\text { Exports } \\
\text { (tons) }\end{array}$ & 383,445 & 342,482 & 441,021 & 421,272 & 430,205 & 494,347 \\
\hline & $\begin{array}{l}\text { Value } \\
(000 \$)\end{array}$ & 899,16 & 0899,848 & $1,233,57$ & $61,231,935$ & $51,328,00$ & $71,328,431$ \\
\hline & $\begin{array}{l}\text { Export K } \\
\text { Auction }\end{array}$ & $\operatorname{Kg} 2.34$ & 2.63 & 2.80 & 2.92 & 3.09 & 2.69 \\
\hline & Price $/ \mathrm{kg}$ & 2.30 & 2.71 & 2.76 & 2.98 & 3.18 & 2.64 \\
\hline & Diff. & 0.04 & $(0.08)$ & 0.04 & $(0.06)$ & $(0.09)$ & 0.05 \\
\hline Sri Lanka & $\begin{array}{c}\text { Exports } \\
\text { (tons) }\end{array}$ & & 279,883 & 296,383 & 301,271 & 306,040 & \\
\hline & $\begin{array}{l}\text { Value } \\
(000 \$)\end{array}$ & $1,195,092$ & $1,145,06$ & $21,299,51$ & $71,357,994$ & $1,324,696$ & $61,462,994$ \\
\hline & $\begin{array}{l}\text { Export K } \\
\text { Auction }\end{array}$ & & 4.09 & 4.38 & 4.514 .33 & 4.73 & \\
\hline & Price/kg & 2.87 & 3.13 & 3.38 & 3.26 & 3.07 & 3.44 \\
\hline & Diff. & 1.15 & 0.96 & 1.00 & 1.25 & 1.26 & 1.29 \\
\hline
\end{tabular}

(Sourced from ITC annual bulletin of statistics 2013)

It was therefore expected that being aware of the inherent benefits of value addition to tea, stakeholders in the sector would work towards ensuring that they enhance the value of this important export commodity before availing it to the world market. The reality on the ground however points to a situation in which very little is being done as the country continues to export much tea but gain little in return. Though some research has been done on aspects of value addition to tea with majority attempting to educate stakeholders on the importance of value addition to tea, none as yet specifically deals with factors that could be inhibiting large scale operationalization of value addition to tea. This study therefore intended to seal this research gap by assessing the influence of factors with specific focus on buyers due to their strategic distributive role in the Kenyan tea trade value chain.

\section{Factors Inhibiting Value Addition to Tea}

Research has shown that several factors could be responsible for limited value addition to products. The study adopted David (2005) analysis of factors affecting strategic management practices of a business entity and conceptualized them as is illustrated in figure 1 .

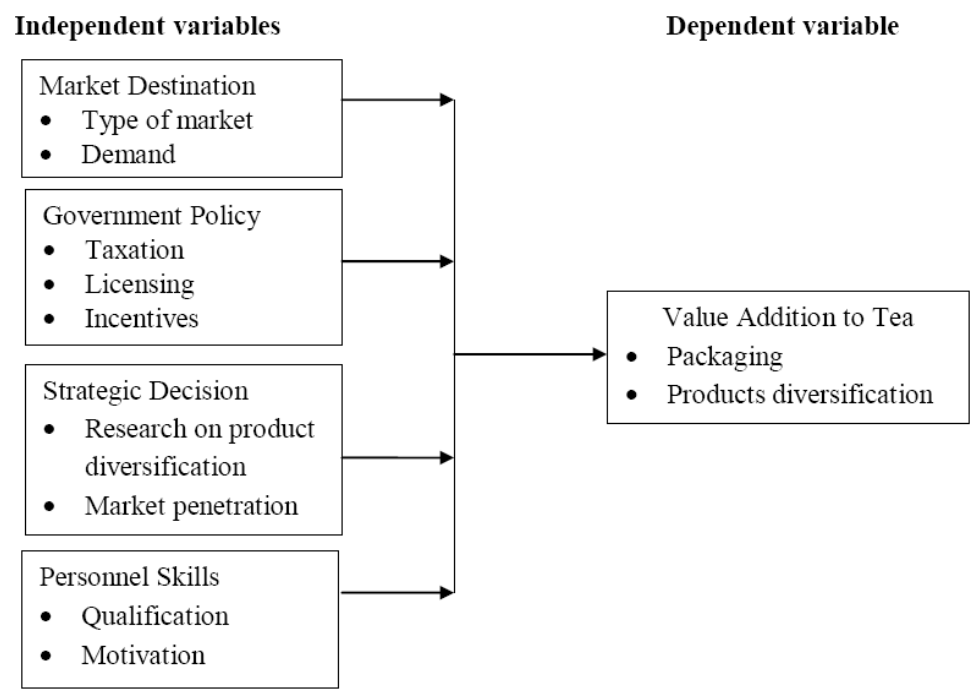

Figure1. Elements of the Conceptual Framework

Figure 1shows the interaction of elements that are perceived to be impacting value addition to tea. Value addition to tea involves a number of factors conceived as the independent variables in this study. The variables include market destinations of tea, Government policy, exporters' strategic management decisions and the exporters' personnel skills (Huselid, Jackson \& Schuler, 1997). 


\subsection{Market Destination}

In last the decade, Kenyan tea has majorly been destined for Pakistan, Egypt, United Kingdom, Afghanistan and Sudan (TBK, 2009) with individual organizations and Tea Board of Kenya being involved in the marketing of the product. Over the same period, marketing of tea has become a fierce battle grounds where both domestic and foreign competitors fight for the market share. Tea from Kenya has won international acclaim for its taste and aroma and is so popular that it is the beverage of choice served in restaurants and cafés in many countries either in pure or blended form (Kenya Information Guide, 2014). In its purest form, Kenyan tea has gained recognition in markets across the world because it has been proved to have higher levels of antioxidants compared to teas produced in other parts of the world. Because pure Kenya tea is very superior in quality compared to other teas of the world, most tea exported from Kenya is sold in blended form - it's used for blending with other teas to produce some of the popular blends available in grocery stores across the United States, Europe, Asia and other markets (TBK, 2014).

Anecdotal reports show that over-dependence on traditional tea markets namely Pakistan, UK, Egypt, Sudan, and Afghanistan, has led to limited market diversification which must be addressed (TBK, 2014). Trade statistics shows that out of the top ten export market destinations for Kenyan products, six are in Africa, namely Uganda, Somalia, Egypt, Rwanda, DRC, and Sudan which are potential markets for Kenyan tea (TBK, 2009). According to MacDonald (2000), high dependency on a particular market; trends and growth in the market size, pricing, trends in purchase patterns, channels of distribution and global competition can result in market risk that hinder new investments or increase in investment for existing firms. Similarly, research has shown that Kenya has over the years relied on production and export of high quality bulk CTC tea, which have been traditionally used as raw material to blend low quality teas from other countries at the expense of Kenyan tea brands (TBK, 2009). Over-reliance on black CTC tea with limited product diversification has led to fluctuation in black tea prices. The industry has also not produced teas for other markets like flavoured teas, green tea, and most recently coloured tea. Could the market destination be a factor inhibiting value addition to tea?

\subsection{Government Policy}

Tea growing in Kenya has developed significantly over the last 80 years in terms of expansion in tea planting, number of growers, production, processing and sales (exports and local sales) with Kenya maintaining a consistent production of high quality tea thus is the leading exporter in the world accounting for $22 \%$ of the global exports (Draft National Tea Policy, 2014). According to the authors of the policy document, the good performance of the industry so far is mainly attributed to Government support, facilitative institutional structure, private sector contribution and growing international demand for Kenyan tea. Primarily therefore, it is the prerogative of the government to create an enabling environment in which production, processing and marketing of tea can thrive optimally for maximum return on investment (Madura, 2006). Thus, the policies that the government put in place can serve to promote or inhibit value addition to tea.

For instance, empirical data shows that the Kenyan government has promoted policies of trade liberalization in the past decade (Kenya information Guide, 2014). While the international financial institutions and Western governments in general tend to support trade liberalization, it may have negative effects for a country like Kenya that depends on agricultural exports in exchange for higher value-added capital imports. If Kenyan manufacturing firms cannot compete with their foreign counterparts, reduction of trade protection measures, such as tariffs, will simply lead to the retardation of the Kenyan industrial sector (Wilson, 1999). The result would be further entrenchment of the agricultural sector in the economy, and thus the prolonging of the unequal trading patterns that sustain the country's severe balance of trade deficit.

Similarly, it is the prerogative of the government to cushion Kenyan investors in the tea industry from conditions imposed by the international bodies that tends to disadvantage them. For instance, it is suggested that the European market is imposing 13 extra taxes on Kenya cut flowers (Wilson, 1999). These taxes include standards levy, local authorities levy etc. The only way out seems to lie in the success of the government lobby to be listed as least developed country, a status which will allow Kenyan exports, tea and cut flowers to access the lucrative EU markets without having to meet the stringent conditions already imposed. 
Additionally, it is alleged that bureaucratic hurdles particularly in developing countries like Kenya have encouraged corruption (Madura, 2006). Macroeconomic uncertainty like currency crashes, high inflation, and excessive budget deficits limit the ability to attract investments. Similarly, good infrastructure has a positive impact on investment flows (Asiedu, 2002), a fact emphasized in EPZA annual report of 2004 that the impediments faced by EPZ Enterprises stem from high cost of doing business in Kenya as a result of low labour productivity, depleted infrastructure, customs regulations and high cost of electricity and water. As such, researchers lament that Kenyan firms pay more unofficial fees, provide more for their own infrastructure and face more regulations than competitors in other countries (Ikiara \& Ndirangu, 2003). For instance, due to unreliable electricity supply, most firms are forced to install private power generators, which were unplanned expenditure (Wanyama, 2003). Similarly, with regard to infrastructure, availability of adequate packaging materials and provision of incentive to large multinationals was a factor that affected value addition to tea in Sri Lanka (USAID - Shri Lanka, 2002) Whether or not these are factors inhibiting value addition to tea in Kenya was a question that this study sought to answer.

\subsection{Strategic Decisions}

Strategic decision is the process through which the management of companies formulates the company's mission, including broad statements about its purpose, philosophy, and goals so as to arrive at the companies short, mid and long term plan of action. It is a part of a firm's strategic management. Strategic management is defined as the set of decisions and actions that result in the formulation and implementation of plans designed to achieve a company's objectives. It involves planning, directing, organizing, and controlling of a company's strategy-related decisions and actions. By strategy, managers arrive at their large-scale, future-oriented plans for interacting with the competitive environment to achieve company objectives. A strategy is a company's "game plan." Although that plan does not precisely detail all future deployments (of people, finances, and material), it does provide a framework for managerial decisions. According to (Barney, 1991) strategic management entails analysis, decisions, and actions an organization undertakes in order to create and sustain competitive advantages.

Similarly, according to Barney and Arikan (2001), strategic management is concerned with the analysis of the hierarchy of the strategic goals (vision, mission, and strategic objectives) along with the analysis of the internal and external environment of the organization. Next, leaders must make strategic decisions. These decisions, broadly speaking, address two basic questions: What industries should a business entity compete in? and how should it compete in those industries? These questions also often involve an organization's domestic as well as its international operations. And last are the actions that must be taken. Decisions are of little use, of course, unless they are acted on. Firms must take the necessary actions to implement their strategies. This requires leaders to allocate the necessary resources and to design the organization to bring the intended strategies to reality.

Thus, the process of analysis strategic goals and the strategic decisions envisaged revolve around the firms marketing strategy, human resource development strategy and research and development strategy to position itself as the low-cost producer, or develop products and services that are unique which will enable the firm to charge premium prices - or some combination of both (Hamel \& Prahalad,1994 and Christenson, 2001). If managers focus only on making minor improvements to their firm's operations, it will be quite easy for competitors to duplicate their moves and take away their advantages in the marketplace. At best, they will be forced to engage in intensive price competition that will erode everyone's profits. At worst, if they direct the vast majority of their efforts to internal operations, they might be blindsided by a new competitor offering a far superior product, service, or technology that just might make their firm irrelevant. In a survey of 1,500 senior leaders, 870 of them CEOs (from 20 different countries), respondents were asked what they believed were the key traits that leaders must have (Lipton, 1996). Ninety eight percent responded that "a strong sense of vision" was the most important. Similarly, when asked about the critical knowledge skills, the leaders cited "strategy formulation to achieve a vision" as the most important skill. In other words, managers need to have not only a vision but also a plan to implement it.

\subsection{Personnel Skills}

Business entities, tea exporters included are staffed and managed by people. Staff training and competence is essential in meeting customer's satisfaction (Cole, 2002) for any business venture. Well trained staff will provide multi-skilled contribution to the overall aims of the organization. The 
employees are thus trained and encouraged to maximize their potential so that organizations can maximize their effectiveness (Wayne, 2003). The question that arises at this juncture therefore is how this can be achieved within the tea export value chain particularly with regard to value addition to tea? An organization can improve its performance through human power development, focused research and support through putting in place appropriate policies as the key to innovation for the entity to meet the capacity in the current market competition (Hiten, 2012). In highlighting one of the immediate needs of stakeholders in the apparel industry in Kenya, the researcher suggested that appropriate training programs for personnel that entail design, production and marketing should be designed to enable personnel to meet the needs of their customers. Thus, for stakeholders within tea value chain, the skills and competence of the personnel within the value chain particularly those within the country could work to enhance or inhibit value addition to tea by buyers before export. The study sought to investigate the contributions of the human resource in the tea export value chain in promoting or inhibiting value addition to tea within the country.

\section{OBJECTIVES OF THE STUDY}

The overall objective of this study was to identify factors affecting value addition to tea by buyers within the value chain of Kenyan tea trade sector.Specifically, the study sought:

- To determine how market destinations affect value addition of tea within the tea industry.

- To determine how Government policy effects value addition to tea by stakeholders in the tea industry.

- To determine how strategic decisions affect value addition of tea by tea buyers within the tea industry.

- To determine how personnel skill affects value addition of tea by tea buyers within the tea industry

\section{RESEARCH METHODOLOGY}

\subsection{Participants and Procedure}

Participants were 39 respondents drawn from 55 different tea buying companies at Mombasa tea auction market. Respondents were sampled from senior management positions within their respective companies in charge of formulation, implementation and monitoring of the company's policy issues thus were the best placed persons to provide an insight into the company's management dynamics. They were told that the study aimed at assessing factors impacting value addition to tea. They completed a questionnaire constructed by the researchers.

\subsection{Measures}

Market destination. Four statements were used to assess the extent to which respondents conceived market destination to be impacting value addition to tea; all ratings were made on a 5-point scale ( $1=$ strongly disagree, $5=$ strongly agree). A mean score of each item was computed.

Government Policy. Seven statements statements were used to assess the extent to which the respondents perceived existing government policies could be impacting their engagement in value addition to tea; all ratings were made on a 5 -point scale $(1=$ strongly disagree, $5=$ strongly agree $)$. A mean score of each item was computed.

Strategic Decisions. Four statements were used to assess the extent to which strategic decisions were perceived to be impacting value addition to tea; all ratings were made on a 5-point scale ( $1=$ strongly disagree, $5=$ strongly agree). A mean score of each item was computed.

Personnel Skills. Five statements were used to determine the extent to which personnel skills could be impacting value addition to tea; all ratings were made on a 5-point scale $(1=$ strongly disagree, $5=$ strongly agree). A mean score of each item was computed.

Dependent Variable. Value addition to tea was measured based on the respondents' conception of the extent to which they were involved in aspects of value addition to tea using two statements assessing aspects of packaging and product diversification. A mean score of each item was computed. 


\section{RESUlTS AND DiscuSSION}

\subsection{Market Destination and Value Addition to Tea}

The study to begin with sought to establish the influence of market destination on value addition to tea. It thus made an inquiry on the respondents' perception of various issues related to market destination of Kenyan tea. Principally, it sought to assess the forms in which most buyers export tea and the destinations of such tea. Of those sampled, 30 (76.9\%) were involved in export, $3(7.7 \%)$ were trading in the local market while $6(15.4 \%)$ were both trading at the local market and export market. Additionally, 23 (59.0\%) indicated exporting tea to less than 5 countries, $9(23.1 \%)$ to between 5 and 10 countries while the remaining 7 (17.9\%) exported more than 10 countries. Thus an assessment of the influence of this destination on value addition to tea was undertaken and the findings were as reported in Table 2.

Table2. Influence of Market Destination on Value Addition to Tea

\begin{tabular}{|lcc|}
\hline Statement & Mean & Std Dev. \\
\hline $\begin{array}{l}\text { The form in which our organization exports } \\
\text { tea is influenced by the type of market we } \\
\text { deal with }\end{array}$ & 4.4103 & .84970 \\
$\begin{array}{l}\text { The type of market our organization deal } \\
\text { with requires blending of tea }\end{array}$ & 3.8974 & 1.07103 \\
$\begin{array}{l}\text { The type of market our organization deal } \\
\text { with requires that we package the tea in } \\
\text { packets of not more than 5 Kgs }\end{array}$ & 2.5385 & 1.35426 \\
Grand Mean & & \\
\hline
\end{tabular}

The results show that the form in which the organizations exports tea has the highest influence thus the indicator had highest mean of 4.41 and a standard deviation of 0.850 . It was followed by the influence of the type of market the organizations deal with that require blending of tea (mean of 3.90 and standard deviation of 1.071) and lastly the type of market that organizations deal with which require that they package tea in packets of $5 \mathrm{kgs}$ or less (mean of 2.54 and standard deviation of 1.354) in decreasing order of influence. The elements of the variable attained an overall mean rating of 3.62 and standard deviation of 1.092 implying that a majority of the respondents felt that market destination influenced value addition to tea. Regression analysis showed that market destination, ( $\beta=$ $0.112 ; \mathrm{p}=.385$ ) has an insignificant negative influence on value addition to tea. Generally, the findings imply that market destination is an inhibitor of value addition to Kenyan tea according to a majority of buyers. This observation corroborates that of MacDonald (2000), who noted that market destination has an influence on value addition to products. The researcher observed that high dependency on a particular market; trends and growth in the market size, pricing, trends in purchase patterns, channels of distribution and global competition can result in market risk that hinder new investments or increase in investment for existing firms. TBK (2014) also observed that over-dependence on traditional tea markets namely Pakistan, UK, Egypt, Sudan, and Afghanistan, has led to limited market diversification which must be addressed. Similarly, TBK (2009) observed that the overreliance of Kenya on black CTC tea with limited product diversification has led to fluctuation in black tea prices in the world market. This according to the researchers could be attributed to fact that Kenya has over the years relied on production and export of high quality bulk CTC tea, which have been traditionally used as raw material to blend low quality teas from other countries at the expense of Kenyan tea brands.

\subsection{Government Policy and Value Addition to Tea}

The second aim of the study was to determine the influence of existing government policyon value addition to tea. The results were as is presented in Table 3.

The findings show that the influence of VAT on packaging material having a negative effect on value addition to tea had the highest rating (mean of 4.26 and standard deviation of 1.069) followed by the influence of VAT on value added tea having a negative effect on value addition to tea (mean of 4.23 and standard deviation of 1.111) then the influence of import duty on machinery for non EPZ facilities (4.05 and standard deviation of 1.100) followed by influence of common user facility on value addition (mean of 3.64 and standard deviation of 1.088). Similarly, statement on the friendliness of procedures on exporting value added tea under EPZ received a relatively higher mean rating (mean of 3.49 and standard deviation of 1.048) followed by the influence of infrastructure within the EPZ that 
encourage value addition to tea (mean of 3.18 and standard deviation of .942) and lastly the influence of the government strategy on market penetration for value added tea (mean of 2.56 and standard deviation of 1.210). Overall therefore, the respondents mean rated the influence of elements of government policy at 3.63 out of 5 and a standard deviation of 1.081. This implies that a significant proportion of the respondents believe that government policies influences value addition to tea. The regression equation showed that government policy $(\beta=0.071 ; \mathrm{p}=.306)$ has a positive insignificant influence on value addition to tea. This agrees with the assertions of Madura (2006) who maintains that it is the prerogative of the government to create an enabling environment in which production, processing and marketing of tea can thrive optimally for maximum return on investment. The researcher alleges that bureaucratic hurdles particularly in developing countries like Kenya have encouraged corruption. Similarly, good infrastructure has a positive impact on investment flows (Asiedu, 2002), a fact emphasized in EPZA annual report of 2004 that the impediments faced by EPZ Enterprises stem from high cost of doing business in Kenya as a result of low labour productivity, depleted infrastructure, customs regulations and high cost of electricity and water.

Table3. Influence of Government Policy on Value Addition to Tea

\begin{tabular}{|lcc|}
\hline Statement & Mean & Std Dev. \\
\hline $\begin{array}{l}\text { VAT on value added teas have negative } \\
\text { effect on value addition of tea. }\end{array}$ & 4.2308 & 1.11122 \\
$\begin{array}{l}\text { VAT on packaging material have negative } \\
\text { effect on value addition of tea }\end{array}$ & 4.2564 & 1.06914 \\
$\begin{array}{l}\text { Import duty on machinery for non EPZ } \\
\text { facilities discourage value addition }\end{array}$ & 4.0513 & 1.09901 \\
$\begin{array}{l}\text { Procedures on exporting value added tea } \\
\text { under EPZ are friendly }\end{array}$ & 3.4872 & 1.04810 \\
$\begin{array}{l}\text { Infrastructure within EPZ encourage value } \\
\text { addition to tea }\end{array}$ & 3.1795 & .94233 \\
$\begin{array}{l}\text { Common user facility will encourage value addition } \\
\text { The government has good strategy in market } \\
\text { penetration for value added tea. }\end{array}$ & 3.6410 & 1.08790 \\
Grand Mean & 2.5641 & 1.20950 \\
\hline
\end{tabular}

\subsection{Strategic Decisions and Value Addition to Tea}

The study also aimed at determining the influence of strategic decisions on value addition to tea. The findings were as summarized in Table 4.

Table4. Influence of Strategic Decisions on Value Addition to Tea

\begin{tabular}{|lcc|}
\hline Statement & Mean & Std Dev. \\
\hline $\begin{array}{l}\text { Our organization is researching on new value } \\
\text { added products for new and current markets } \\
\begin{array}{l}\text { Our organization has developed new value } \\
\text { added products }\end{array}\end{array}$ & 3.7692 & 1.03775 \\
$\begin{array}{l}\text { Our organization intends to move into new } \\
\text { market for value added tea }\end{array}$ & 3.3077 & 1.15060 \\
$\begin{array}{l}\text { Our organization have put in place plans to } \\
\text { increase the amount of value added tea it is } \\
\text { currently exporting } \\
\text { Grand Mean }\end{array}$ & 3.8205 & .91398 \\
\hline
\end{tabular}

Table 4 contains information on respondents' conception of the influence of elements of strategic decisions on value addition to tea. The results show that a majority of the respondents felt that the intention of the company's to move into new market for value added product had the greatest influence thus the highest mean rating of 3.82 and standard deviation of .914. Similarly, respondents were categorical that the prospect of organizations researching on new value added products for new and current markets also received a higher mean rating of 3.77 and 1.038, followed by the intentions of the organizations to put in place plans to increase the amount of value added tea that they are exporting (mean of 3.33 and standard deviation of 1.284) and lastly the intention of the organizations to develop new value added products (mean of 3.31 and standard deviation of 1.151). Thus the element attained a mean ranking of 3.56 and standard deviation of 1.100 indicating that a majority of the respondents perceive strategic decisions to be of great influence on value addition to tea. Results from the regression equation $(\beta=0.291, p<.008)$ shows that strategic decisions have a significant 
positive influence on value addition to tea. The finding is in supports of previous findings. According to Barney and Arikan (2001), strategic management is concerned with the analysis of the hierarchy of the strategic goals (vision, mission, and strategic objectives) along with the analysis of the internal and external environment of the organization. The researchers stress that leaders must make strategic decisions which broadly speaking, address two basic questions: What industries should a business entity compete in? and how should it compete in those industries? Similarly, empirical data shows that the process of analysis strategic goals and the strategic decisions envisaged revolve around the firms marketing strategy, human resource development strategy and research and development strategy to position itself as the low-cost producer, or develop products and services that are unique which will enable the firm to charge premium prices - or some combination of both (Hamel \& Prahalad, 1994 and Christenson, 2001).

\subsection{Personnel Skills and Value Addition to Tea}

Lastly, the study set out to determine the influence of personnel skills on value addition to tea. Results obtained were as summarized in Table 5.

Table5. Influence of Personnel Skills on Value Addition to Tea

\begin{tabular}{|lcc|}
\hline Statement & Mean & Std Dev. \\
\hline $\begin{array}{l}\text { Our company has qualified personnel who } \\
\text { research on value added tea products }\end{array}$ & 3.7949 & 1.05580 \\
$\begin{array}{l}\text { Our company has enough qualified personnel } \\
\text { who develop value added tea products for the market }\end{array}$ & 3.7949 & 1.03057 \\
$\begin{array}{l}\text { Our organization has enough skilled personnel } \\
\text { who manufacture value added products }\end{array}$ & 3.4359 & 1.11909 \\
$\begin{array}{l}\text { Our organization has qualified people who } \\
\text { aggressively market value added tea products }\end{array}$ & 3.3846 & 1.16111 \\
$\begin{array}{l}\text { Our company offers its staff incentives for } \\
\text { innovation in value addition }\end{array}$ & 3.2308 & 1.13466 \\
Grand Mean & 3.5282 & 1.10025 \\
\hline
\end{tabular}

The findings show that as an element of personnel skills, the respondents indicated that the prospect of their company having qualified personnel who research on value added products and the that fact that their company have qualified personnel who develop value added tea products for the market have the greatest influence on value addition to tea thus the high mean ranking of 3.79 and standard deviations of 1.056 and 1.031 respectively. Similarly, a greater proportion of the respondents felt that having enough skilled personnel who manufacture value added products by an organization influences value addition to tea (mean of 3.44 and standard deviation of 1.119) followed by the influence of an organization with qualified people who aggressively market value added tea products (mean of 3.38 and standard deviation of 1.161) and lastly the influence of incentives offered by a company to its staff for innovation in value addition (mean of 3.23 and standard deviation of 1.135). In general therefore, the respondents mean rated the influence of elements of personnel skill on value addition to tea at 3.53 and a standard deviation of 1.100. Results from regression analysis, $(\beta=0.212, p=.011)$ implied that personnel skill also had a significant positive influence on value addition to tea. This could be interpreted to mean that a significant proportion of the respondents felt that personnel skills influences value addition to tea which concurs with observations of previous researchers who believe that business entities, tea exporters included are staffed and managed by people who are technically competent to discharge duties expected of them. Staff training and competence is essential in meeting customer's satisfaction (Cole, 2002) for any business venture. Well trained staff will provide multiskilled contribution to the overall aims of the organization. The employees are thus trained and encouraged to maximize their potential so that organizations can maximize their effectiveness (Wayne, 2003).

\section{IMPLICATIONS, LiMitATIONS AND CONCLUSION}

\subsection{Implications for Tea Trade Value Chain}

According to our findings, value addition to tea within the tea trade value chain by buyers is influenced by a number of factors including market destination, existing government policies, strategic decisions and personnel skills. With market destinations indicated to be the main inhibitor, stakeholders need to consider diversifying to new markets. In the course of this, specific attention should be given to new markets that would allow exportation of highly value added tea products 
rather than the traditional ones that mainly order for bulk tea with minimal or no value addition. Additionally, the government should put in place mechanisms aimed at addressing its policies inhibiting value addition to tea while the management of tea buying companies should deliberately formulate policies aimed at encouraging value addition to tea including providing incentives to their employees involved in value addition.

\subsection{Limitations and Directions for Further Research}

The main limitation of this study rests on its quantitative methodology which mainly depended on self-report measures. It is encouraged that future studies could build on these by applying mixed study methods and longitudinal studies that can track changes in thinking processes and related consumer and investment related issues. It should also be noted that the findings of the present study have to be interpreted in a careful way since a convenience sampling procedure was applied. Respondents were drawn from senior management personnel who could have been bias in their reporting in an attempt to give favourable import of their company's dispositions.

\subsection{Conclusion}

On the whole, the study has provided insight into factors perceived to be influencing value addition to tea in Kenya, a buyers' context. The findings suggest that overreliance on the traditional Kenyan tea market destinations with a penchant for bulk tea with minimal or no value addition is the main inhibitor of effort of buyers to value add Kenyan tea before export. The results show that stakeholders need to seriously consider minimizing overdependence on the country's traditional world market tea trade partners who appears to be the main beneficiaries of the minimally value added tea that the country exports.

\section{REFERENCES}

Asiedu, E. (2002). "On the determinants of foreign direct investment to developing Countries. Is Africa different?" World Development, 30(1): 107-19.

Barney, J. B. (1991). Firm resources and sustained competitive advantage. Journal of Management vol 17 No. 1, 99-120.

Cole, G.A. (2002).Strategic management, theory and practice $2^{\text {nd }}$ Edition. Singapore; South -western cengage learning.

David, F.R. (2005). Strategic Management: Concepts and Cases, Tenth Edition. Prentice Hall, Pearson Education International.

Hiten, M. (2012). Challenges of foreign direct investment firms in the apparel manufacturing industry in the Kenyan export processing zones. An unpublished research project report submitted in partial fulfilment of the requirement for the award of the degree of master of business administration, school of business, university of Nairobi.

Huselid, M.A., Jackson, S.E. \& Schuler, R.S., (1997.). "Technical and Strategic Human Resourse Management Effectiveness as Determinants of Film Performance. Academy of Management Journal 40(199), 171-188.

Ikiara ,M \& Ndirangu,L., (2003) ."Prospects of Kenya's clothing Exports under AGOA after 2004,KenyaInstitute for Public Policy Research and Analysis (KIPPRA), Nairobi ,Kenya

International Tea Committee (ITC) (2013). Annual Bulletin of Statistics Supplement 2012.

Madura, J. (2006). International Financial Management, $8^{\text {th }}$ edition. Cengage Learning.

Ochanda, S. O. (2012). A Review of Development of the Tea (camelia sinensis) Industry in Kenya and Possible Areas of Exploitation for Value Addition. African Journal of Horticultural Science (June 2012) 6:53-60.

TBK. (2009). Tea Board of Kenya Statistics. Nairobi: Tea Board of Kenya.

Tea Board of Kenya (2014). Feasibility Study on Establishment of Tea Value Addition Facilities in Kenya. Nairobi; M.A Consulting Group.

Wanyama, J.M (2003) " Analysis of Factors affecting operations of firms in Export Processing Zones in Kenya" Unpublished Master of Business Administration Project, University of Nairobi.

Wayne, F.C.(2003).Managing Human Resource, productivity, quality of work life, profits, Tata McGraw-Hill $6^{\text {th }}$ Edition.

Willson K. (1999). Coffee, Cocoa and Tea. Wallingford, UK: CAB International. 


\section{AUTHORS' BIOGRAPHY}

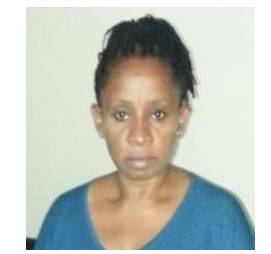

Mrs. Grace S. Tsalwa, hold a Bachelor of Science Degree in Botany and Zoology. She works as a Tea Executive in Africa Tea Brokers Limited, a leading tea broking company at the Mombasa tea auction, Kenya. She is a Master of Business Administration student at Jomo Kenyatta University of Agriculture and Technology, Mombasa campus.

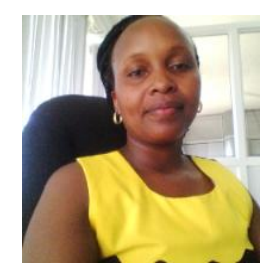

Dr. Fridah Theuri, is the Deputy Director- Jomo Kenyatta University of Agriculture and Technology, Mombasa Campus and Senior lecturer in the School of Human Resource and Development. 